Review

International Journal of Biological Sciences

ISSN 1449-2288 www.biolsci.org 2008 4(5): 283-290

(C) Ivyspring International Publisher. All rights reserved

\title{
Advances in Susceptibility Genetics of Intervertebral Degenerative Disc Disease
}

\section{Yin'gang Zhang ${ }^{1 凶}$, Zhengming Sun'1, Jiangtao Liu'1, Xiong Guo²}

1. Department of Orthopaedics of the First Affiliated Hospital, Medical College of Xi'an Jiaotong University, Xi'an, 710061, China

2. Key Laboratory of Environment and Genes Related Diseases of Ministry of Education, Xi'an Jiaotong University, Xi'an, 710061, China

$\triangle$ Correspondence to: Dr. Yin'gang Zhang, Department of Orthopaedics of the First Affiliated Hospital, Medical College of Jiaotong University, Xi'an, 710061, China, E-mail: zyingang@mail.xjtu.edu.cn, Tel: +86-029-85323935

Received: 2008.06.27; Accepted: 2008.08.31; Published: 2008.09.02

The traditional view that the etiology of lumbar disc herniation is primarily due to age, gender, occupation, smoking and exposure to vehicular vibration dominated much of the last century. Recent research indicates that heredity may be largely responsible for the degeneration as well as herniation of intervertebral discs. Since 1998, genetic influences have been confirmed by the identification of several genes forms associated with disc degeneration. These researches are paving the way for a better understanding of the biologic mechanisms. Now, many researchers unanimously agree that lumbar disc herniation appears to be similar to other complex diseases, whose etiology has both environmental and hereditary influence, each with a part of contribution and relative risk. Then addressing the etiological of lumbar disc herniation, it is important to integrate heredity with the environment factors. For the purpose of this review, we have limited our discussion to several susceptibility genes associated with disc degeneration.

Key words: Intervertebral disc Disease; Degeneration; Candidate Genes; Familial Aggregation

\section{Introduction}

Intervertebral vertebral disc is a link between the adjacent two vertebrae, which includes anulus fibrosus outside and nucleus pulposus inside. It can buffer the pressure came from the upper body and lower extremities to maintain the physical height and movement of spine. Lumbar disc herniation is that nucleus pulposus protrudes from the defective anulus fibrosus because of its degeneration and it's a common and important cause of low back pain. The traditional view that the etiology of lumbar disc herniation was primarily due to age, gender, occupation, smoking and exposure to vehicular vibration dominated much of the last century [1]. The contribution of other factors such as height, weight and genetics is less certain [2]. In recent years, however, a dramatic advance has been made in our understanding of genetic influences on the risk for disc degeneration, thus changing our traditional views. Genetic factors, in particular, may be largely responsible for the degeneration as well as herniation of intervertebral disc [3]. As Ala-Kokko concluded in her paper, "Even though several envi- ronmental and constitutional risk factors have been implicated in this disease, their effects are relatively minor. And recent family and twin studies have suggested that sciatica, disc herniation and disc degeneration may be explained to a large degree by genetic factors" [4]. Now, many researchers unanimously agree that lumbar disc herniation appears to be similar to other complex diseases, whose etiology has both environmental and hereditary influence, each with a part of contribution and relative risk. Then addressing the etiological of lumbar disc herniation, it is important to integrate heredity with the environment factors. For the purpose of this review, we have limited our discussion to several susceptibility genes associated with disc degeneration. Following is a brief review regarding the genetics of disc degeneration, selected from more extensive articles on the same subject.

\section{Familial Aggregation of Disc Degeneration and Heritability}

The first step in the study of genetic epidemiology is typically to determine if there is a familial ag- 
gregation of the condition or the disease of interest, which suggests the possibility of a genetic influence.

In 1991, Varlotta et al [5] found that $32 \%$ of adolescent patients with disc herniation had a family history. Matsui et al [6] reported that there is familial clustering of lumbar disc herniation among the encumbrances of 18-year-old or younger patients with lumbar disc herniation. Subsequently, in 1995, Battie et al [7] assessed lumbar MRIs of 115 pairs of male monozygotic twins, to investigate the relative effects of environmental risk factors, age and familial aggregation on disc degeneration. Disc bulging, height narrowing, and disc desiccation as indicated through signal intensity were used as phenotypic clinical markers. In a multivariable analysis of the No.12 thoracic-No.4 lumbar vertebrae region, physical loading exposures explained $7 \%$ of the variance in disc degeneration scores among the 230 subjects, with the addition of age to $16 \%$ and with the addition of a variable representing familial aggregation to $77 \%$. In the No.4-5 lumbar vertebrae and No. 5 lumbar-No.1 sacral vertebrae region, physical loading measures explained only $2 \%$ of the variance in disc degeneration summary scores in multivariable analysis. The variance score in lower lumbar rose to $9 \%$ with the addition of age and to $43 \%$ with the addition of familial aggregation. This study provided the first estimate of the relative importance of specific environmental agents and overall familial influences including genetic factors. In 1997, Matsui et al [8] analyzed responses from a questionnaire given by 3, 042 Japanese workers at a factory. They found that the average age of the first attack of low back pain in workers whose parents also suffered from the same condition, was significantly younger than that in workers with no similar history.

After the evidence for familial aggregation of disc degeneration was established, there was a need to distinguish between biologic (genetic) and social (cultural inheritance) sources of familial similarity. Sambrook et al [9] conducted a classic twin study to examine the hypothesis that disc degeneration has a major genetic component. Spine MRIs were obtained from 86 pairs of monozygotic twins and 154 dizygotic twins, $80 \%$ of whom were female, from Australian and British twin registries. A substantial genetic influence on disc degeneration was found. For a summary score of disc degeneration, comprised of disc height, signal intensity, bulging, and anterior osteophyte formation, heritability estimates were very high, 74\% (95\% confidence interval, $64 \%-81 \%$ ) for the lumbar spine and
$73 \%$ (95\% confidence interval, $64 \%-80 \%$ ) for the cervical spine, after adjusting for age, weight, smoking, occupation, and physical activity. The analysis on the individual MRI findings suggested that disc bulging and height were the primary contributors to genetic determination of the disc degeneration summary score. However, the genetic influence on signal intensity was not apparent.

In summary, the observations and studies in juveniles and adults of familial aggregation make a convincing case that intervertebral disc herniation is indeed influenced by familial factors. The studies do not, however, provide data on the relative contributions of genetic and shared environmental factors among family members. However, these findings indicate that stronger genetic effects are associated with an earlier onset of intervertebral disc degeneration.

\section{Approaches in studying genetic traits of lumbar disc herniation}

At present, approaches of genome-wide scan and candidate-gene have been used in the study of complex diseases by single nucleotide polymorphism (SNPs), which is used as a genetic marker. The candidate-gene approach has been widely used to study susceptibility genes of complex diseases [10]. By literature searches, researchers would find disc metabolism pathway specific-genes, which may be correlated with phenotype of lumbar disc herniation. Then, patients with final diagnosis and normal controls matched with the study group are researched by a case-control study and association study, to compare SNPs of candidate-gene that play a key role in the pathway of disc metabolism or locate the relative domain of chromosome. Its purpose is to select potential susceptible gene by analyzing whether the frequency of gene in two groups has statistical difference. There are four major categories of candidate-genes related to lumbar disc disease (Fig. 1). Category 1 includes the genes association with the construction of the structural component of the intervertebral disc, such as the aggrecan gene and the collagen IX gene. Category 2 consists of genes that produce the degradation enzymes of the disc matrix, for example, the matrix metalloprotease- 3 gene. Category 3 is comprised of the genes related to bone structure. The osteoporosis related genes, vitamin-D receptor and estrogen receptor genes, are implicated in lumbar disc disease. Category 4 is others. 


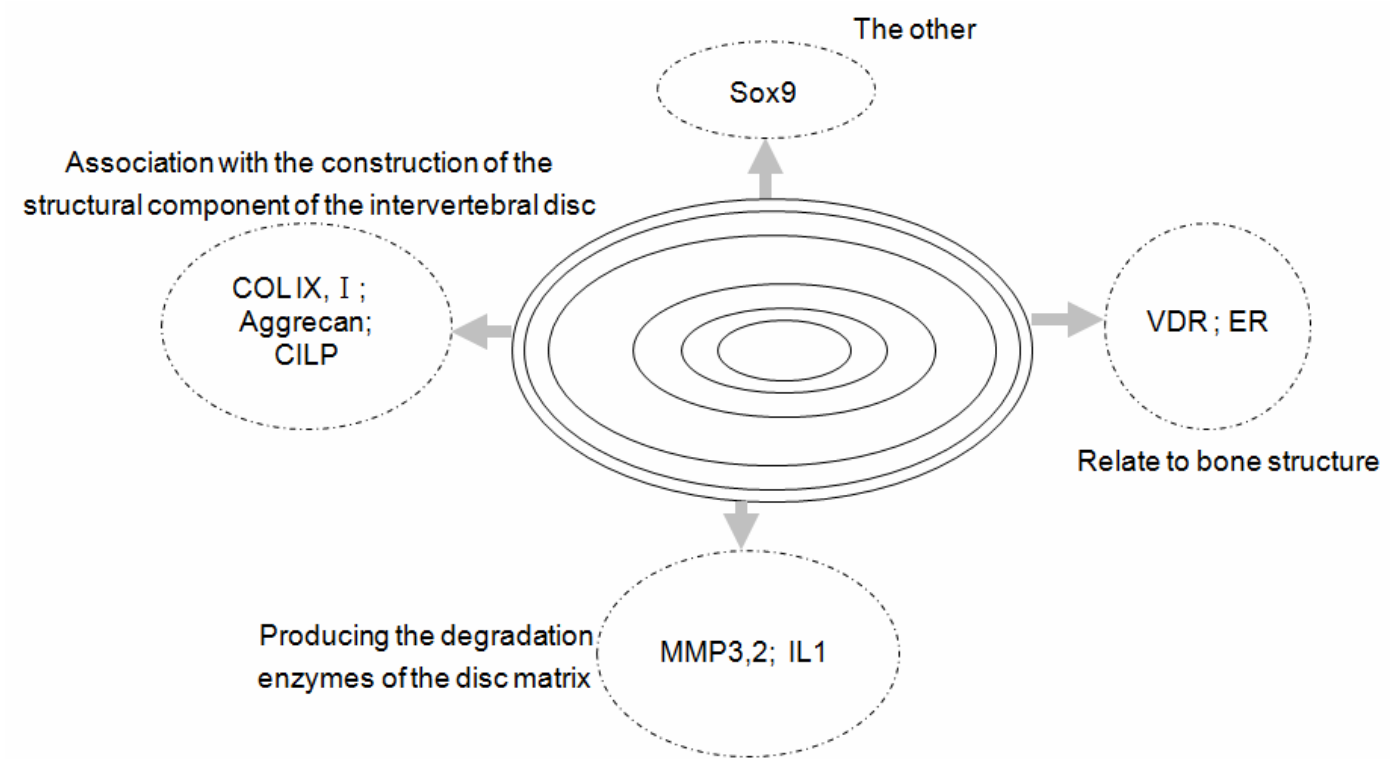

Figure 1. Categories of candidate-genes related to lumbar disc disease. Note $\mathrm{COL}=\mathrm{Collage}$; $\mathrm{CILP}=$ cartilage intermediate layer protein; MMP=Matrix metalloprotease; $\mathrm{IL}=$ interleukin; VDR=Vitamin D receptor; $\mathrm{ER}=$ estrogen receptor; Sox9=SRY (sex-determining region Y)-box9 encoding

\section{Candidate-gene polymorphisms associated with disc degeneration}

\subsection{Type IX collagen}

Collagen IX, a structural component of nucleus pulposus and annulus fibrosus of intervertebral disc, is considered to serve as a bridge between collagens and non-collagenous proteins in tissues. It is a heterotrimer of three Alpha chains, 1(IX), 2(IX), and 3(IX), encoded by the genes COL9A1, COL9A2, and COL9A3, respectively. It consists of three collagenous (COL1 to COL3) and four non-collagenous (NC1 to NC4) domains [11]. Collagen IX shares an important role to constitute intervertebral disc, so gene encoding collagen IX is suitable candidate-genes. And COL9A2 and COL9A3 genes are relatively better studied than COL9A1 (references see below). Transgenic mice expressing mutant alpha $1(\mathrm{IX})$ collagen were reported to have accelerated disc degeneration [12].

\subsubsection{COL9A2}

In 1999, Annunen et al [13] pointed out that allele of COL9A2 act a significant role in the pathogenesis of disc disease. Studies indicated a heterozygous substitution of Trp for either Gln ${ }^{326}$ or Arg An $^{326}$ in the COL2 domain changed the structure of collagenous domains of COL2. Because Trp is rarely found in collagenous domains, there are no Trp residues in the collagenous domains of collagen IX in humans or in the mouse [14]. Like many hydrophobic amino acids, Trp may disrupt the collagen triple helix, as well as interfere with the interaction between collagens IX and II or prevent the action of lysyl oxidase, which catalyzes cross-link formation, and thus cause disc disease. Annunen et al used conformation sensitive gel electrophoresis to analyze all the exons and exon boundaries of COL9A2 in patients with the Trp substitution. The analysis did not identify any other possible causes of the disease in the coding sequences or RNA splice sites, but it indicated two additional changes, an A to $G$ change affecting the third nucleotide in the codon for proline (CCA to CCG) at nucleotide 9 in exon 21, and a $\mathrm{G}$ to $\mathrm{A}$ change at nucleotide +17 in intron 30 .

An outcome of conspicuous heredity and phenotype was discovered in a Finnish population carrying allele COL9A2 with the $\operatorname{Trp}(\operatorname{Tr} 22)$ substitution. The Trp 2 allele was found in 6 of 157 Finnish patients (4\%) but in none of 174 control individuals. Coinheritance of the Trp 2 allele and the phenotype was studied in the families of four original patients. All members who had inherited the allele in these families had intervertebral disc disease [13]. Jim et al [15] reported that Trp2 allele has a higher frequency in a Southern Chinese population than in a Finnish population. The Trp2 allele was present in $20 \%$ of 804 samples. Affected Trp 2 individuals had more severe degeneration, moreover, the association was age-dependent $[15,16]$. Seki et al [17] reported Trp2 was common in Japanese, and no association with lumbar disc degeneration was apparent. However, association of a COL9A2 specific haplotype with lumbar disc degeneration was detected. Accordingly, the allelic variation of COL9A2 
that is associated with lumbar disc disease is dependent on race and nationality.

\subsubsection{COL9A3}

In the case-control study of the Finnish population of relative homogeneity, Petteri et al [18] found that for an individual carrying allele COL9A3 with the $\operatorname{Trp}(\operatorname{Trp} 3)$ substitution, the risk of disc disease increased nearly 3-fold compared with an individual without Trp3. The site of mutation was an Arg103 $\rightarrow \operatorname{Trp}$ substitution in the a3 (IX) chain (Trp3allele). A study of 164 individuals with lumbar disc disease and 321 controls (186 healthy, 83 with osteoarthritis, 31 with rheumatoid arthritis, and 21 with chondrodysplasia), showed the frequency of the Trp3 allele as $12.2 \%$ in the case sample and $4.7 \%$ in the control group, the differences were statistically significant. The results indicated that the Trp3 allele may cause lumbar disc disease. But, it is noteworthy that the association with Trp3 allele in the Finnish population has not been successfully replicated in the Greek population [19].

Solovieva's [20] study found that the carriage of the Trp3 allele in the absence of the IL-1betaT (3954) allele increased the risk of dark nucleus pulposus and joint occurrence of degenerative changes by MRI. There was no effect of the Trp3 allele on disc degeneration in the presence of the IL-1betaT (3954) allele. The outcomes suggest that the effect of the COL9A3 gene polymorphism on disc degeneration may be modified by the IL-1beta gene polymorphism. The Trp3 allele was also associated with radiographic features of Scheuermann disease [21].

Solovieva et al [22] had further researched the relation of gene-environment interaction, and found that incidence rate of lumbar disc degeneration was increased for interactions of the mutation of COL9A3 gene with persistent load on disc. In a study of 135 male individuals with Trp3, it was discovered that the incidence rate of lumbar disc degeneration was $71 \%$ in obese patients compared with only $45 \%$ in subjects who were not obese. It is thus evident that prevalence of disc degeneration could be strikingly increased when there is the synergistic effect of gene-environment interaction.

\subsection{Type I collagen}

Collagen I is an important ingredient of bone and anulus fibrosus of disc. Pluijm et al [23] and Tilkeridis et al [24] reported that the risk of disc degeneration for people with the TT genotype was higher than people with the GG or GT genotype. Mann found that presence of the $T$ allele in the COLIA1 Sp1 binding site has functional effects on the collagen gene regulation that leads to a higher COLIA1 mRNA expression level, an increase COLIA1 protein expression level and COLIA1/COLIA2 protein ratios [25]. An abnormal ratio of collagen is associated with impaired bone structure. Moreover, the intronic polymorphism of the Sp1 binding site of COLIA1 may affect the transcription of collagen I. There may be interactions with other genes or environmental factors. However, how defects in collagen I influence the development of disc degeneration is still unclear and needs further investigation. The relative interpretation between gene and disease has disparity. Therefore, association analysis with large sample size is indispensable to research the relation between the Sp1 binding site of COLIA1 and disc degeneration.

\subsection{Type IV and $X$ collagen}

Wang et al [26] reported that type IV collagen occurring in the disc of adolescents is the result of early cellular reaction to harmful stimuli, and this can serve as a biological marker for early degeneration of human lumbar intervertebral discs. Nerlich et al [27] found that collagen type $X$ was expressed by nuclear chondrocytes at a higher age and was associated with advanced degenerative disc alterations. Hence both of them may be taken as molecular markers of disc degeneration. To date, there are no known associations of polymorphisms in collagen type IV and/or collagen type $\mathrm{X}$ genes, with intervertebral disc disease.

\subsection{Sox9}

Sox9 is one of a family of genes related to the mammalian Y-linked, testis-determining gene Sry [28]. Sox genes appear to encode transcription factors with diverse roles in differentiation and development. Sox 9 is expressed in mesenchymal condensations prior to and during chondrogenesis, and it has been shown to activate Col2a1, the gene encoding type II collagen, the major component of cartilage matrix $[29,30]$. Sox 9 has been shown to regulate the genes encoding aggrecan [31] and type XI collagen [32], and may also regulate other structural and/or patterning gene involved in cartilage and bone development [33]. Expression and regulation of Sox 9 gene also were seen at the nucleus pulposus cells [34].

Paul et al [35] have explored the use of Sox9 gene therapy for degenerative disc disease. They used adenoviral delivery vectors expressing $\operatorname{Sox} 9$ to infect a chondroblastic cell line and human disc cells; Sox 9 and Type II collagen production increased. In addition, AdSox9 virus was injected directly into the discs of rabbits, they have reported that the expression was preserved for 5 weeks. Gruber et al considered that loss of expression of Sox9 in some of the anulus cell population may play a role in disc aging and degeneration, possibly by decreased modulation of the ex- 
pression and production of Type II collagen of disc cells [36]. Sox9 is co-expressed with Col2a1. Mutation and polymorphism of Sox9 gene and association with intervertebral disc degeneration remain to be studied.

\subsection{Vitamin D receptor}

Studies found that Vitamin D receptor play an important role in normal bone mineralization and remodeling, and its gene polymorphisms are thought to correlate with some disease. Videman et al [37] and Kawaguchi et al [38] reported that subjects with the $t t$ or $T t$ allele of the vitamin-D receptor gene were more frequently associated with multilevel and severe disc degeneration and disc herniation than ones with the TT allele. They pointed an increased risk of disc disease at an early age in subjects with the Tt allele in the vitamin-D receptor gene. On the other hand, in an evaluation of the association between allelic variations in the vitamin-D receptor gene and spinal degenerative disease, Jones et al [39] found a sharp decrease in the risk of spinal osteophytosis and the presence of disc narrowing between $t t$ and TT. Spinal osteophytosis and disc narrowing are closely related to disc degeneration. Furthermore, Videman et al [40] found two intragenic polymorphisms of the vitamin $D$ receptor gene associated with disc degeneration. Quantitatively assessed signal intensities of thoracic and lumbar (No.6 thoracic-No.1 sacral vertebrae) discs were $12.9 \%$ worse in men with the Taql tt genotype and 4.5\% worse in men with the Tt genotype, compared with signal intensity in men with the TT genotype. A similar pattern was found between disc signal intensity and Fok $l$ polymorphisms; men with the $f f$ and $F f$ genotypes had mean signal intensities that were 9.3\% and $4.3 \%$ lower, respectively, than those in men with FF genotypes. The summary scores of qualitatively assessed signal intensity, bulging, and disc height were $4.0 \%$ and $6.9 \%$ worse in men with $\mathrm{Ff}$ and $f f$ genotypes, respectively, when compared with those in men with the FF genotype. Cheung et al [41] had further confirmed that the $t$ allele of vitamin $D$ receptor Taq I was associated with a high risk of degenerative disc disease and disc bulge developing, especially in individuals younger than 40 years.

It has been reported that the vitamin-D receptor is expressed not only in osteoblasts [42] but also in the chondrocytes [43]. Balmain et al found immunoreactive vitamin-D receptor in the nucleoli of the chondrocyte, particularly in the fibrillar component, suggesting that vitamin $\mathrm{D}$ is directly involved in the differentiation, proliferation, and maturation of cartilage cells. In addition, vitamin D can influence proteoglycan synthesis by articular chondrocytes in vitro [44]. Since the intervertebral disc is also rich in proteogly- can, these findings suggest that the vitamin-D receptor may be directly involved in the pathophysiology of the degenerated intervertebral disc. At present, it is still unknown how the genetic variants of the vitamin$D$ receptor gene affect the clinical presentation of disc disease. Kawaguchi et al speculated that this polymorphism in the vitamin-D receptor gene might alter the structural characteristics of the matrix in the intervertebral disc [38]. Furthermore, he further considered the possibility that vitamin-D receptor gene polymorphism is not directly involved in the pathogenesis of lumbar disc disease but merely a marker for other genes. The vitamin-D receptor gene is located on chromosome 12q12 [45]. The type-2 collagen (COL2A1) gene and insulin-like growth factor (IGF) type-1 gene are also located nearby [46]. It is likely genetic marker of degenerative disc disease.

\subsection{Matrix metalloprotease-3}

Studies suggest that matrix metalloprotease-3 (MMP-3) has an important role in the degeneration of intervertebral discs [47]. MMP-3 expression is induced in response to local conditions such as mechanical loading [48] and inflammation [49]. A common 5A/6A polymorphism in the promoter region of the human MMP-3 gene has been identified [50].This polymorphism was reported to be involved in the regulation of MMP-3 gene expression with the $5 A$ allele having twice as much promoter activity as the $6 \mathrm{~A}$ allele [51]. Takahashi et al [52] studied elderly Japanese subjects, and found that the $5 A 5 A$ and $5 A 6 A$ genotype in the elderly was associated with a significantly larger number of degenerative intervertebral discs than the $6 A 6 A$, but there was no significant difference in the young. These studies indicate that the $5 \mathrm{~A}$ allele of the human $M M P-3$ promoter may be a crucial risk factor for the acceleration of intervertebral disc degeneration, especially in the older population.

\subsection{Interleukin-1}

Inflammatory cytokines have a well-recognized contribution to the generation of back pain. Interleukin-1 in particular contributes to disc degeneration by inducing enzymes that destroy proteoglycan and it is involved in the mediation of pain. Solovieva et al $[53,54]$ have demonstrated an association between interleukin-1 polymorphisms and features of disc degeneration on magnetic resonance imaging in male Finnish workers. The TT genotype of the IL-1 gene was associated with more than a 3-fold increase in the risk of disc bulges among middle-aged occupationally active men. The polymorphisms were associated with a 2.5-fold increased risk of back pain, and an association was also seen with the intensity and duration of pain together, with the degree of functional limitation. 
Ye et al [55] have suggested $-511 T>C$ SNP in $I L-1 \beta$ gene associates with Lumbar disc disease in Chinese.

Besides, Valdes have tested polymorphisms of genes that express inflammatory factors, and found some of the same polymorphisms, such as CD36, COX2, NCOR2, TNA and ESR1, affecting knee OA susceptibility, were also associated with radiographic progression of lumbar disc degeneration [56]. Polymorphisms of gene of cartilage intermediate layer protein were associated with the pathogenesis of lumbar disc disease [57].

\section{Overview}

Lumbar disc degeneration is not only regulated by multiple genes and some environmental factors, but also gene-gene interactions and gene-environment interactions may also exist. At present, the study of allele of COL9A2 is more extensive than the other genes associated with lumbar disc disease. However, it is necessary for long-term study and research to integrate larger sample size with clinical and controlled study of different populations. Study of allele of COL9A3, vitamin D receptor and matrix metalloprotease-3 gene were only confined to the superficial correlation of elementary and clinical research. Hereditary and mechanism of these genes are still unknown. The role of collagen and its gene mutation, which occur frequently in the pathogenesis of lumbar disc disease, has been researched to a certain extent. However, it is essential to perform further research in order to better understand the interrelation of genetic genes and environmental factors. With the continual development of genome-wide scan, effective means is offered to find numerous genes, each with a small overall contribution to the pathogenesis of lumbar disc degeneration. Researchers may delimit a specific domain by genome-wide scan and then scan eligible SNPs located in the domain, find virulence genes by analysis of linkage disequilibrium, in order to search for early biomarkers for susceptible individuals.

Although the complex contributions and interactions of genetic and environmental factors are largely unknown, work has begun in this area. On the whole, genetic study with relation to lumbar disc disease would offer new evidence for prevention and cure of lumbar disc disease.

\section{Acknowledgement}

We are grateful for the support from The Natural Scientific Fund of China (No. No.30400163) and The Clinical Researched Fund of First Affiliated Hospital of Medical College of Xi'an Jiaotong University. Special thanks are given to Professor Deng Chu-Xia for the instructive suggestions and the critical comments from referees.

\section{Conflict of Interest}

The authors have declared that no conflict of interest exists.

\section{References}

1. Borenstein DG. Epidemiology, etiology, diagnostic evaluation, and treatment of low back pain. Curr Opin Rheumatol. 2001; 13: 128-134.

2. Frymoyer JW. Lumbar disk disease: epidemiology. Instr Course Lect.1992; 41: 217-223.

3. Battié MC, Videman T, Levalahti E, Gill K, Kaprio J. Heritability of low back pain and the role of disc degeneration. Pain. 2007; 131: 272-280.

4. Ala-Kokko L. Genetic risk factors for lumbar disc disease. Ann Med.2002; 34: 42-47.

5. Varlotta GP, Brown MD, Kelsey JL, Golden AL. Familial predisposition for herniation of a lumbar disc in patients who are less than twenty-one years old. J Bone Joint Surg Am.1991; 73: 124-128.

6. Matsui H, Terahata N, Tsuji H, Hirano N, Naruse Y. Familial predisposition and clustering for juvenile lumbar disc herniation. Spine.1992; 17: 1323-1328.

7. Battié MC, Videman T, Gibbons LE, Fisher LD, Manninen H, Gill K. 1995 Volvo Award in clinical sciences. Determinants of lumbar disc degeneration. A study relating lifetime exposures and magnetic resonance imaging findings in identical twins. Spine.1995; 20: 2601-2612.

8. Matsui H, Maeda A, Tsuji H, Naruse Y. Risk indicators of low back pain among workers in Japan. Association of familial and physical factors with low back pain. Spine.1997; 22: 1242-1247.

9. Sambrook PN, MacGregor AJ, Spector TD. Genetic influences on cervical and lumbar disc degeneration: a magnetic resonance imaging study in twins. Arthritis Rheum.1999; 42: 366-372.

10. Tabor HK, Risch NJ, Myers RM. Candidate-gene approaches for studying complex genetic traits: practical considerations. Nat Rev Genet.2002; 3: 391-397.

11. Morris NP, Bächinger HP. Type XI collagen is a heterotrimer with the composition (1 alpha, 2 alpha, 3 alpha) retaining non-triple-helical domains. J. Biol. Chem.1987; 262: 11345-11350.

12. Kimura T, Nakata K, Tsumaki N, Miyamoto S, Matsui $Y$, Ebara $\mathrm{S}$, Ochi T. Progressive degeneration of articular cartilage and intervertebral discs. An experimental study in transgenic mice bearing a type IX collagen mutation. Int Orthop.1996; 20: 177-181.

13. Annunen $S$, Paassilta $P$, Lohiniva J, Perälä $M$, Pihlajamaa $T$, Karppinen J, Tervonen $\mathrm{O}$, Kröger $\mathrm{H}$, Lähde S, Vanharanta $\mathrm{H}$, Ryhänen L, Göring HH, Ott J, Prockop DJ, Ala-Kokko L. An allele of COL9A2 associated with intervertebral disc disease. Science.1999; 285: 409-412.

14. Muragaki Y, Kimura T, Ninomiya Y, Olsen BR. The complete primary structure of two distinct forms of human alpha 1 (IX) collagen chains. Eur J Biochem.1990; 192: 703-708.

15. Jim JJ, Noponen-Hietala N, Cheung KM, Ott J, Karppinen J, Sahraravand A, Luk KD, Yip SP, Sham PC, Song YQ, Leong JC, Cheah KS, Ala-Kokko L, Chan D. The TRP2 allele of COL9A2 is an age-dependent risk factor for the development and severity disc degeneration. Spine.2005; 30: 2735-2742.

16. Tigashino K, Matsui $Y$, Yagi S, Takata Y, Goto T, Sakai T, Katoh $\mathrm{S}$, Yasui N. The alpha2 type IX collagen tryptophan polymorphism is associated with the severity of disc degeneration in younger patients with herniated nucleus pulposus of the lumbar spine. Int Orthop. 2007; 31: 107-111. 
17. Seki S, Kawaguchi Y, Mori M, Mio F, Chiba K, Mikami Y, Tsunoda T, Kubo T, Toyama Y, Kimura T, Ikegawa S. Association study of COL9A2 with lumbar disc disease in the Japanese population. J Hum Genet. 2006; 51: 1063-1067.

18. Paassilta P, Lohiniva J, Göring HH, Perälä M, Räinä SS, Karppinen J, Hakala M, Palm T, Kröger H, Kaitila I, Vanharanta $\mathrm{H}$, Ott J, Ala-Kokko L. Identification of a novel common genetic risk factor for lumbar disc disease. JAMA.2001; 285: 1843-1849.

19. Kales SN, Linos A, Chatzis C, Sai Y, Halla M, Nasioulas G, Christiani DC. The role of collagen IX tryptophan polymorphisms in symptomatic intervertebral disc disease in Southern European patients. Spine.2004; 29: 1266-1270.

20. Solovieva S, Lohiniva J, Leino-Arjas P, Raininko R, Luoma K, Ala-Kokko L, Riihimäki H. Intervertebral disc degeneration in relation to the COL9A3 and the IL-1ss gene polymorphisms. Eur Spine J. 2006; 15: 613-619.

21. Karppinen J, Pääkkö E, Paassilta P, Lohiniva J, Kurunlahti M, Tervonen O, Nieminen P, Göring HH, Malmivaara A, Vanharanta $\mathrm{H}$, Ala-Kokko L. Radiologic phenotypes in lumbar MR imaging for a gene defect in the COL9A3 gene of type IX collagen. Radiology. 2003; 227: 143-148.

22. Solovieva S, Lohiniva J, Leino-Arjas P, Raininko R, Luoma K, Ala-Kokko L, Riihimäki H. COL9A3 gene polymorphism and obesity in intervertebral disc degeneration of the lumbar spine: evidence of gene-environment interaction. Spine. 2002; 27: 2691-2696.

23. Pluijm SM, van Essen HW, Bravenboer N, Uitterlinden AG, Smit JH, Pols HA, Lips P. Collagen type I alpha1 Sp1 polymorphism, osteoporosis, and intervertebral disc degeneration in older men and women. Ann Rheum Dis. 2004; 63: 71-77.

24. Tilkeridis C, Bei T, Garantziotis S, Stratakis C. Association of a COL1A1 polymorphism with lumbar disc disease in young military recruits. J Med Genet. 2005; 42: e44.

25. Mann V, Hobson EE, Li B, Stewart TL, Grant SF, Robins SP, Aspden RM, Ralston SH. A COLIA1 Sp1 binding site polymorphism predisposes to osteoporotic fracture by affecting bone density and quality. J Clin Invest. 2001; 107: 899-907.

26. Wang Xiangda, Chen Bohua, Hu Yougu. Expression of collagen type IV in human lumbar intervertebral discs. Journal of Qingdao University Medical College. 2005; 41: 207-209.

27. Nerlich AG, Schleicher ED, Boos N. 1997 Volvo Award winner in basic science studies. Immunohistologic markers for age-related changes of human lumbar intervertebral discs. Spine. 1997; 22: 2781-2795.

28. Wright E, Hargrave MR, Christiansen J, Cooper L, Kun J, Evans T, Gangadharan U, Greenfield A, Koopman P. The Sry-related gene Sox 9 is expressed during chondrogenesis in mouse embryos. Nat Genet. 1995; 9: 15-20.

29. Bell DM, Leung KK, Wheatley SC, Ng LJ, Zhou S, Ling KW, Sham MH, Koopman P, Tam PP, Cheah KS. SOX9 directly regulates the type-II collagen gene. Nat Genet.1997; 16: 174-178.

30. Lefebvre V, Huang W, Harley VR, Goodfellow PN, Crombrugghe B. SOX9 is a potent activator of the chondrocyte-specific enhancer of the pro alpha1(II) collagen gene. Mol Cell Biol. 1997; 17: 2336-2346.

31. Sekiya I, Tsuji K, Koopman P, Watanabe H, Yamada Y, Shinomiya K, Nifuji A, Noda M. Sox9 enhances aggrecan gene expression via the promoter region containing a signal HMG-BOX-sequence in a chondrogenic cell line, TC6. J Biol Chem. 2000; 275: 10738-10744.

32. Bridgewater LC, Lefebvre V, de Crombrugghe B. Chondrocyte-specific enhancer elements in the Col11a2 gene resemble the Col2a1 tissue-specific enhancer. J Biol Chem. 1998; 273: 14998-15006.

33. Genzer MA, Bridgewater LC. A Col9a1 enhancer element activated by two interdependent SOX9 dimers. Nucleic Acids Res. 2007; 35(4): 1178-86.
34. Sive JI, Baird P, Jeziorsk M, Watkins A, Hoyland JA, Freemont AJ. Expression of chondrocyte markers by cells of normal and degenerate intervertebral discs. Mol Pathol.2002; 55: 91-97.

35. Paul R, Haydon RC, Cheng H, Ishikawa A, Nenadovich N, Jiang W, Zhou L, Breyer B, Feng T, Gupta P, He TC, Phillips FM. Potential use of Sox 9 gene therapy for intervertebral degenerative disc disease. Spine.2003; 28: 755-763.

36. Gruber HE, Norton HJ, Ingram JA, Hanley EN Jr. The SOX9 transcription factor in the human disc: decreased immunolocalization with age and disc degeneration. Spine.2005; 30: 625-630.

37. Videman T, Gibbons LE, Battie MC, Maravilla K, Vanninen E, Leppavuori J, Kaprio J, Peltonen L. The relative roles of intragenic polymorphisms of the vitamin D receptor gene in lumbar spine degeneration and bone density. Spine.2001; 26: E7-E12.

38. Kawaguchi Y, Kanamori M, Ishihara H, Ohmori K, Matsui H, Kimura T. The Association of Lumbar Disc Disease with Vitamin-D Receptor Gene Polymorphism. J Bone Joint Surg Am. 2002;84A: 2022-2028

39. Jones G, White C, Sambrook P, Eisman J. Allelic variation in the vitamin D receptor, lifestyle factors and lumbar spinal degenerative disease. Ann Rheum Dis.1998; 57: 94-99.

40. Videman T, Leppävuori J, Kaprio J, Battié MC, Gibbons LE, Peltonen L, Koskenvuo M. Intragenic polymorphisms of the vitamin $\mathrm{D}$ receptor gene associated with intervertebral disc degeneration. Spine.1998; 23: 2477-2485.

41. Cheung KM, Chan D, Karppinen J, Chen Y, Jim JJ, Yip SP, Ott J, Wong KK, Sham P, Luk KD, Cheah KS, Leong JC, Song YQ. Association of the Taq I allele in vitamin D receptor with degenerative disc disease and disc bulge in a Chinese population. Spine. 2006; 31: 1143-1148.

42. Amizuka N, Ozawa H. Intracellular localization and translocation of 1 alpha, 25-dihydroxyvitamin D3 receptor in osteoblasts. Arch Histol Cytol. 1992; 55: 77-88.

43. Balmain N, Hauchecorne M, Pike JW, Cuisinier-Gleizes P, Mathieu H. Distribution and subcellular immunolocalization of 1, 25-dihydroxyvitamin D3 receptors in rat epiphyseal cartilage. Cell Mol Biol (Noisy-le-grand) .1993; 39: 339-350.

44. Corvol MT, Dumontier MF, Tsagris L, Lang F, Bourguignon J. Cartilage and vitamin D in vitro (author's transl). Ann Endocrinol (Paris). 1981; 42: 482-487.

45. Pedeutour F, Merscher S, Durieux E, Montgomery K, Krauter K, Clevy JP, Barcelo G, Kucherlapati R, Gaudray P, Turc-Carel C. Mapping of the 12q12- q22 region with respect to tumor translocation breakpoints. Genomics .1994; 22: 512-518.

46. Labuda M, Fujiwara TM, Ross MV, Morgan K, Garcia-Heras J, Ledbetter DH, Hughes MR, Glorieux FH. Two hereditary defects related to vitamin $\mathrm{D}$ metabolism map to the same region of human chromosome 12q13-14. J Bone Miner Res.1992;7: 1447-1453

47. Goupille P, Jayson MI, Valat JP, Freemont AJ. Matrix metalloproteinases: the clue to intervertebral disc degeneration? Spine.1998; 23: 1612-1626.

48. Handa T, Ishihara H, Ohshima H, Osada R, Tsuji H, Obata K. Effects of hydrostatic pressure on matrix synthesis and matrix metalloproteinase production in the human lumbar intervertebral disc. Spine.1997; 22: 1085-1091.

49. Ito A, Mukaiyama A, Itoh Y, Nagase H, Thogersen IB, Enghild JJ, Sasaguri Y, Mori Y. Degradation of interleukin 1betaby matrix metalloproteinases. J Biol Chem.1996; 271: 14657-14660.

50. Ye S, Watts GF, Mandalia S, Humphries SE, Henney AM. Preliminary report: genetic variation in the human stromelysin promoter is associated with progression of coronary atherosclerosis. Br Heart J. 1995; 73: 209-215.

51. Ye S, Eriksson P, Hamsten A, Kurkinen M, Humphries SE, Henney AM. Progression of coronary atherosclerosis is associated with a common genetic variant of the human stromelysin-1 promoter which results in reduced gene expression. J Biol Chem. 1996; 271: 13055-13060. 
52. Takahashi M, Haro H, Wakabayashi Y, Kawa-uchi T, Komori H, Shinomiya K. The association of degeneration of the intervertebral disc with $5 \mathrm{~A} / 6 \mathrm{~A}$ polymorphism in the promoter of the human matrix metalloproteinase-3 gene. J Bone Joint Surg. 2001; 83B: 491-495.

53. Solovieva S, Kouhia S, Leino-Arjas P, Ala-Kokko L, Luoma K, Raininko R, Saarela J, Riihimäki H. Interleukin 1 polymorphisms and intervertebral disc degeneration. Epidemiology. 2004; 15: 626-633.

54. Solovieva S, Leino-Arjas P, Saarela J, Luoma K, Raininko R, Riihimäki H. Possible association of interleukin1 gene locus polymorphisms with low back pain. Pain. 2004; 109: 8-19.

55. Ye W, Ma RF, Su PQ, Huang DS, Liu SL, Chen WJ, Wang XG. Association of single nucleotide polymorphisms of IL-1B with lumbar disc disease. Yi Chuan. 2007; 29: 923-928.

56. Valdes AM, Hassett G, Hart DJ, Spector TD. Radiographic Progression of Lumbar Spine Disc Degeneration Is Influenced by Variation at Inflammatory Genes: A Candidate SNP Association Study in the Chingford Cohort. Spine. 2005; 30: 2445-2451.

57. Seki S, Kawaguchi Y, Chiba K, Mikami Y, Kizawa H, Oya T, Mio F, Mori M, Miyamoto Y, Masuda I, Tsunoda T, Kamata M, Kubo T, Toyama Y, Kimura T, Nakamura Y, Ikegawa S. A functional SNP in CILP, encoding cartilage intermediate layer protein, is associated with susceptibility to lumbar disc disease. Nat Genet, 2005; 37: 607-612. 